\title{
PENGGUNAAN BERBAGAI GARAM DAN BUMBU PADA PENGOLAHAN PINDANG IKAN LELE DUMBO (Clarias gariepinus)
}

\section{The Use of Various Salt and Spices on Boiled Salted Catfish (Clarias gariepinus) Processing}

\author{
Theresia Dwi Suryaningrum ${ }^{1 *}$, Syamdidi ${ }^{1}$, dan Erna Maya Rizki ${ }^{2}$ \\ ${ }^{1}$ Balai Besar Penelitian dan Pengembangan Pengolahan Produk dan Bioteknologi Kelautan dan Perikanan, KKP. \\ Jl. K.S. Tubun Petamburan VI, Jakarta Pusat 10260 \\ 2 Universitas Sultan Ageng Tirtayasa, Jalan Raya Jakarta KM. 04 Pakupatan, Kota Serang-Banten \\ * Korespondensi Penulis: theresiadwi@yahoo.com
}

Diterima: 17 Oktober 2012, Disetujui: 26 April 2013

\begin{abstract}
ABSTRAK
Telah dilakukan penelitian untuk mengetahui teknik pengolahan pindang ikan lele. Penelitian ini dibagi menjadi 2 tahap yaitu penelitian pendahuluan untuk mengetahui pengaruh perendaman ikan lele segar pada berbagai larutan garam (tawas/Al $\mathrm{SO}_{4}, \mathrm{CaSO}_{4}, \mathrm{CaCl}_{2}, \mathrm{Ca}(\mathrm{OH})_{2}$, dan STPP), terhadap sifat sensoris pindang yang dihasilkan. Sedangkan penelitian utama dilakukan untuk mengetahui pengaruh perendaman garam terbaik hasil penelitian pendahuluan dan asam cuka serta konsentrasi bumbu $(0 ; 5 ; 7,5$; dan $10 \%$ b/b) terhadap sifat mutu pindang yang dihasilkan. Pengamatan pindang dilakukan terhadap sifat kimia (proksimat dan $\mathrm{pH}$ ), adanya cemaran mikroba (Angka Lempeng Total, Escherichia coli, dan Salmonella) serta sifat sensori pindang yang dihasilkan dengan menggunakan uji kesukaan hedonik dan uji skor. Hasil pengamatan terhadap sifat sensori pindang lele yang direndam dalam berbagai larutan garam pada penelitian pendahuluan menunjukkan bahwa perendaman ikan dalam larutan tawas menghasilkan kenampakan, bau, tekstur dan rasa pindang yang lebih baik dibandingkan dengan garam lainnya. Pengolahan pindang ikan lele dengan perlakuan perendaman dalam larutan tawas dan cuka serta perendaman bumbu hanya berpengaruh terhadap kadar abu dan protein, sebaliknya perlakuan tersebut di atas tidak berpengaruh terhadap kadar air, lemak, serta cemaran mikroba pindang yang dihasilkan. Perendaman dalam bumbu menghasilkan pindang yang lebih disukai oleh panelis. Penggunaan bumbu juga dapat menghindari terjadinya kelengketan antar produk. Pindang ikan lele yang diberi perlakuan perendaman dalam larutan tawas dan diberi bumbu dengan konsentrasi 7,5\% menghasilkan pindang yang paling baik dibandingkan dengan perlakuan lainnya.
\end{abstract}

KATAKUNCl: $\quad$ lele, larutan garam, mutu pindang

\section{ABSTRACT}

Study on boiled salted catfish to reveal processing techniques have been carried out. This experiment was divided into two stages: a preliminary study to determine the effect of fish soaking in various salts $\left(\mathrm{Al}_{2} \mathrm{SO}_{4}, \mathrm{CaSO}_{4}, \mathrm{CaCl}_{2}, \mathrm{Ca}(\mathrm{OH})_{2}\right.$ and STPP), while the main study was conducted to determine the effect of selected salt (from preliminary study), vinegar and seasoning concentrations $(0 ; 5 ; 7.5$ and $10 \% \mathrm{w} / \mathrm{W})$ on the quality and consumer acceptance rate of boiled salted catfish. The observations conducted in this research were chemical analysis (proximate and $\mathrm{pH}$ ), microbial analysis (Total Plate Count, the presence of Escherichia coli and Salmonella) and sensory test (preference test and scoring test). The results showed that $\mathrm{Al}_{2} \mathrm{SO}_{4}$ could improve the appearance, odor and texture of boiled catfish compared to other salts. The use of $\mathrm{Al}_{2} \mathrm{SO}_{4}$, vinegar and seasoning as a soaking media in this research statistically gave significant effect on ash content and protein content; on the other hand those variables gave insignificant effect on moisture content, fat content, and Total Plate Count (TPC). Soaking treatment in seasoning solution produced boiled salted catfish preferred by panelist and could avoid the stickiness between products. Boiled salted catfish soaked in $\mathrm{Al}_{2} \mathrm{SO}_{4}$ solution and flavored with a $7.5 \%$ seasoning concentration produced the best product.

KEYWORDS: catfish, chemical salt, quality of salted boiled fish 


\section{PENDAHULUAN}

Pindang merupakan salah satu hasil olahan ikan yang banyak digemari masyarakat. Di Indonesia, pengolahan pindang menempati urutan ke-2 setelah ikan asin, sehingga dapat digunakan sebagai bahan pangan untuk memenuhi gizi masyarakat. Pengolahan tersebut dilakukan dengan merebus atau memanaskan ikan dalam suasana bergaram selama waktu tertentu di dalam suatu wadah (Wibowo, 2000). Pemanasan dan penggaraman dalam pengolahan berfungsi untuk menginaktifkan enzim, membunuh mikroba pathogen, mengubah sifat fisik, sehingga mudah dicerna serta memperbaiki citarasa dan tekstur (Kotacepe et al., 2011). Umumnya konsentrasi garam yang digunakan dalam pengolahan pindang tidak terlalu tinggi atau kurang dari $5 \%$ sehingga produk ini lebih disukai dibandingkan ikan asin (Riyanto et al.,2011).

Di Indonesia terdapat 65.000 usaha pengolahan pindang yang tersebar di berbagai daerah (Anon., 2012). Dari industri yang ada diperlukan bahan baku sekitar 5.261,28 ton/hari atau sebesar 157.838 ton/ bulan (Fallah, 2012). Sementara produksi tangkap nasional jenis ikan yang umumnya diolah sebagai bahan baku pindang hanya 76.343 ton/bulan, sehingga diperkirakan Indonesia kekurangan bahan baku untuk pindang sebesar 81.404 ton/bulan atau 51,5\% dari total kebutuhan ikan pindang nasional. Di lain pihak ikan budidaya yang produksinya terus meningkat seperti ikan mas (Cyprinus carpio), ikan nila (Oreochromis niloticus), ikan mujair (Oreochromis mosambicus), ikan tawes (Puntius javanicus) dan ikan nilem (Osteochilus hasselti) telah diolah menjadi pindang khususnya di Jawa Barat. Sedangkan pengolahan lele menjadi pindang masih belum lazim dilakukan. Lele biasanya diolah dengan cara digoreng, dipepes, dipanggang atau di asap. Masalah yang dihadapi dalam pengolahan ikan lele menjadi pindang adalah teksturnya yang lembek. Hal ini disebabkan karena lele hidup dalam lingkungan perairan umum seperti sungai, danau, situ, kolam yang kadar garamnya 0\%. Pada umumnya ikan mengandung kadar garam di dalam tubuhnya sekitar $1 \%$ namun pada ikan air tawar kadar garam dalam túbuhnya kurang dari 0,1\% (Boyd 1982 dalam Praseno, 2010). Sedangkan menurut Ratnasari (2002) ikan air tawar mempunyai kadar air yang tinggi sekitar $75-82 \%$ sehingga menyebabkan tekstur dagingnya lembek. Selain itu, lele merupakan ikan yang tidak bersisik, warnanya hitam dan mudah berlendir setelah ikan mati, yang jumlahnya sekitar 2-3\% dari masa ikan (Tanako \& Osako, 2009), sehingga dapat menimbulkan masalah dalam proses pengolahannya.

Untuk meningkatkan tekstur serta memucatkan kulit ikan lele, maka dalam pengolahannya menjadi pindang, perlu diberi perlakuan pendahuluan dengan perendaman dalam garam atau asam cuka. Perendaman dalam garam atau asam cuka dimaksudkan untuk memperbaiki tekstur, serta mereduksi adanya lendir dan memucatkan kulit lele yang berwarna hitam. Beberapa garam yang dapat digunakan untuk memperbaiki tekstur adalah tawas (alumunium sulfat/ $/ \mathrm{Al}_{2} \mathrm{SO}_{4}$ ), kalsium sulfat (batu tahu/ $\mathrm{CaSO}_{4}$ ), kalsium klorida/ $\left(\mathrm{CaCl}_{2}\right)$, dan kapur tohor/ $\mathrm{Ca}(\mathrm{OH})_{2}$ (Winarno, 2004). Menurut Taylor (1980) garam tersebut banyak digunakan untuk pembuatan pickle buah atau sayur dengan konsentrasi $0,2 \%$ (b/ v). Nurahman \& Isworo (2005) menyatakan bahwa perendaman ikan dalam larutan tawas sebesar 1\% mampu menurunkan kadar air ikan, karena adanya reaksi osmotik yang menarik air keluar dari sel sel jaringan ikan. Sedangkan penelitian Haribi \& Yusrin (2004) terhadap ikan tongkol asap yang sebelumnya direndam dengan larutan tawas 4-10\% selama 30150 menit, menghasilkan tekstur ikan asap yang lebih kompak dan residu tawas yang aman bagi kesehatan. Sedangkan tawas $\left(\mathrm{AL}_{2}\left(\mathrm{SO}_{3}\right) 14 \mathrm{H}_{2} \mathrm{O}\right)$ adalah garam kimia yang dalam bahan pangan dianggap aman oleh Food and Drug Administration bila digunakan menurut prosedur yang disarankan (Kvech \& Edwards, 2002). Di Jepang untuk meningkatkan tekstur, ikan direndaman dalam asam cuka dengan konsentrasi 2\% selama 1 malam (Tanako \& Osako, 2009). Menurut Winarno (2004) asam cuka pada makanan dapat berfungsi sebagai penegas rasa, warna, pengawet serta sebagai bahan pengembang dan dapat mendenaturasi protein sehingga menurunkan daya ikat air.

Pengolahan pindang ikan air tawar di masyarakat dilakukan dengan menggunakan bumbu, sejenis bumbu pepes sehingga produk yang dihasilkan berbeda dengan produk pindang ikan laut pada umumnya. Penggunaan bumbu ini selain digunakan untuk meningkatkan cita rasa serta menutupi adanya rasa lumpur yang sering terdapat pada ikan air tawar, juga dapat meningkatkan kenampakan pindang ikan yang diolah (Aceng, Komunikasi Pribadi, 2012). Oleh karena itu dalam penelitian ini akan dipelajari pengaruh perendaman larutan garam kimia dan cuka serta konsentrasi bumbu terhadap mutu dan sifat sensori pindang ikan lele yang dihasilkan.

\section{METODE}

\section{Bahan}

Ikan lele yang digunakan dalam penelitian diperoleh dari Parung, Bogor dengan berat rata-rata $161,5 \mathrm{~g}$, panjang total $27,96 \mathrm{~cm}$, panjang badan 17,1 $\mathrm{cm}$, tebal $3,1 \mathrm{~cm}$, lebar $3,36 \mathrm{~cm}$. Sebelum diolah 
menjadi pindang, lele diberok selama semalam dalam bak penampung dengan menggunaan air bersih dan diberi aerasi. Sedangkan bahan bantu yang digunakan adalah garam (tawas $/ \mathrm{Al}_{2} \mathrm{SO}_{4}$ ), $\mathrm{CaCl}_{2}, \mathrm{Ca}(\mathrm{OH})_{2}, \mathrm{STPP}$, $\left.\mathrm{CaSO}_{4}\right)$, garam dapur, bumbu yang terdiri dari bawang putih, kunyit, lengkuas, jahe, sere, salam, dan gula serta bahan kimia untuk analisa kimia dan mikrobiologi.

\section{Metode}

Penelitian ini dibagi menjadi 2 tahap yaitu penelitian pendahuluan dan penelitian utama. Penelitian pendahuluan dilakukan untuk mencari jenis garam terbaik yang dapat meningkatkan tekstur daging ikan lele yang dihasilkan. Sebelum direndam lele dipingsankan dengan menggunakan shock suhu rendah $\left( \pm 4^{\circ} \mathrm{C}\right)$ selama 15 menit, selanjutnya disiangi dengan menghilangkan isi perutnya. Garam yang digunakan adalah tawas/ $\mathrm{Al}_{2} \mathrm{SO}_{4}, \mathrm{CaSO}_{4}, \mathrm{CaCl}_{2}$, $\mathrm{Ca}(\mathrm{OH})_{2}$ dan STPP dengan konsentrasi 0,2\% (b/v) (Taylor, 1980). Perendaman lele dilakukan selama 30 menit dengan perbandingan antara larutan garam dan ikan $1: 1$. Selama perendaman diamati perubahan kondisi ikan secara visual dan terhadap pindang diamati secara sensori dengan menggunakan metode deskriptif. Pengamatan dilakukan dengan menggunakan panelis terlatih terhadap kenampakan, warna, tekstur, dan rasa.

Penelitian utama dilakukan untuk mengetahui pengaruh perendaman dalam garam kimia terbaik (dari hasil percobaan pendahuluan) dan cuka serta konsentrasi bumbu 0; 5; 7,5; dan 10\% (b/b) terhadap berat ikan lele yang diolah menjadi pindang. Sedangkan formula bumbu pindang didasarkan formulasi bumbu pepes lele dumbo hasil penelitian Muljanah dan Suryaningrum ( 2009) yaitu bawang putih $1,2 \%$, lengkuas $1 \%$, kunyit $1 \%$, jahe $0,2 \%$, salam $1 \%$, sereh $1 \%$, garam $5 \%$, dan gula $5 \%$. Bumbu dihaluskan dengan menggunakan mesin blender dengan menambahkan air sebanyak $50 \%$ dari berat bumbu, sehingga berbentuk pasta. Ikan kemudian direndam dalam pasta bumbu dengan berbagai konsentrasi perlakuan $0 ; 5 ; 7,5 ; 10 \%(b / b)$ selama 30 menit. Ikan lele yang telah dibumbui kemudian ditempatkan dalam naya yang terbuat dari anyaman bambu, masing masing naya diisi dengan 3 ekor ikan lele. Lele kemudian dikukus dengan suhu pengukusan berkisar antara $95-98^{\circ} \mathrm{C}$ selama $1 \mathrm{jam}$. Pindang yang diperoleh kemudian dioven pada suhu $60-70^{\circ} \mathrm{C}$ selama 1 jam. Penelitian dilakukan dengan menggunakan 3 kali ulangan. Diagram alir pengolahan pindang lele dapat dilihat pada Gambar 1.

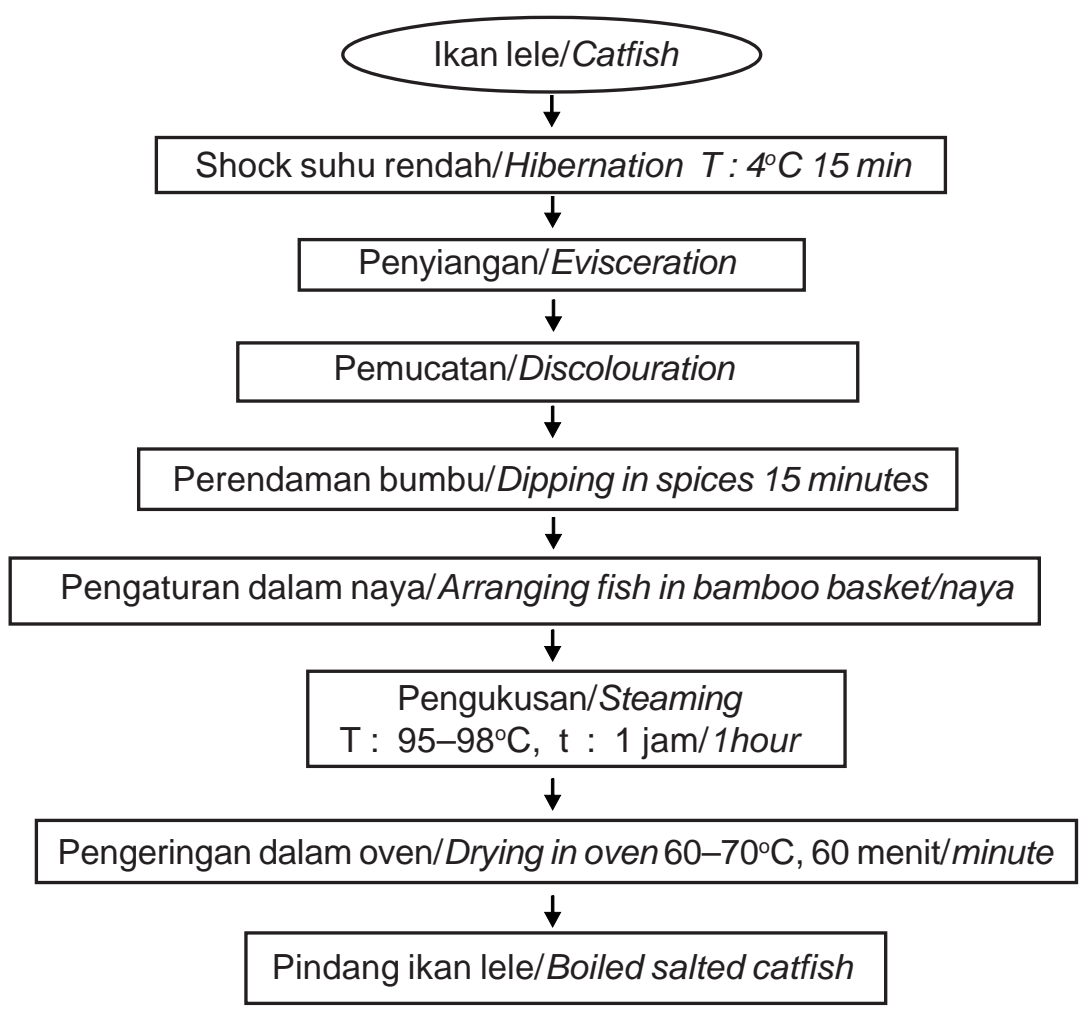

Gambar 1. Diagram alir proses pengolahan pindang ikan lele.

Figure1. Processing flow of boiled salted catfish. 
Pengamatan parameter kimia dilakukan terhadap lele segar dan pindang ikan lele yang meliputi kadar air, kadar abu, kadar protein, dan kadar lemak serta $\mathrm{pH},\left(\mathrm{BSN}, 2006^{\mathrm{a}}\right)$, dan TVB dengan menggunakan metode Conway. Sedangkan uji mikrobiologi dilakukan terhadap angka lempeng total (ALT), Escherichia coli dan Salmonella dengan menggunakan kit Compact dry $\mathrm{T}^{\mathrm{M}}$ untuk E. coli dan Salmonella (BSN, 2006 ${ }^{\mathrm{b}}$ ) serta uji organoleptik dilakukan terhadap tingkat kesukaan dengan menggunakan uji hedonik skala
1-7 serta uji skor (BSN, 2006c) dengan menggunakan panelis terlatih.

\section{HASIL DAN BAHASAN}

\section{Penelitian Pendahuluan}

Hasil pengamatan ikan lele selama perendaman dalam berbagai bahan kimia serta pindang yang dihasilkan dapat dilihat pada Tabel 1. Perendaman

Tabel 1. Hasil pengamatan secara visual ikan lele dan pindang ikan yang direndam dalam berbagai larutan garam

Table 1. Catfish and boiled salted catfish appearences after soaking in various salts solution

\begin{tabular}{|c|c|c|c|}
\hline $\begin{array}{l}\text { Jenis Garam/ } \\
\text { Kind of Salt }\end{array}$ & $\begin{array}{c}\text { Kondisi lkan selama } \\
\text { Perendaman/Fish Condition } \\
\text { during Dipping in Salt Solution }\end{array}$ & $\begin{array}{l}\text { Kondisi lkan setelah } \\
\text { Perendaman/Fish } \\
\text { Condition after Dipping } \\
\text { in Salt Solution }\end{array}$ & $\begin{array}{c}\text { Kondisi Pindang setelah Dioven/Boiled } \\
\text { Salted Condition after Dyring }\end{array}$ \\
\hline $\mathrm{Al}_{2} \mathrm{SO}_{4}$ & $\begin{array}{l}\text { Ikan tidak licin, lendir } \\
\text { menggumpal,air perendam } \\
\text { berwarna kemerahan/Not } \\
\text { slippery, coagulated of slime, } \\
\text { reddish solution }\end{array}$ & $\begin{array}{l}\text { Ikan mengalami } \\
\text { perubahan } \\
\text { warna/Discolouration }\end{array}$ & $\begin{array}{l}\text { Kenampakan rapi, utuh, kurang } \\
\text { bercahaya, bau segar harum, tekstur } \\
\text { padat kurang kompak dan rasa enak, } \\
\text { gurih/Neat appearance, undamage, } \\
\text { less shiny, freshy odor, less compact } \\
\text { texture, but tastefull }\end{array}$ \\
\hline $\mathrm{CaCl}_{2}$ & $\begin{array}{l}\text { Ikan agak licin, sedikit } \\
\text { berlendir, air peren dam jernih } \\
\text { ISlightly slippery skin, less } \\
\text { slimy, clear solution }\end{array}$ & $\begin{array}{l}\text { Ikan mengalami peru } \\
\text { bahan warna } \\
\text { sedikit/Slightly } \\
\text { discoloured }\end{array}$ & $\begin{array}{l}\text { Kenampakan rapi, utuh, agak kusam, } \\
\text { bau segar, kurang harum, tekstur } \\
\text { padat, kurang kompak dan rasa enak } \\
\text { kurang gurih/Neat apperance, } \\
\text { undamage, slighly dull, less freshy, } \\
\text { less compact, tastefull but less savory. }\end{array}$ \\
\hline $\mathrm{Ca} \mathrm{SO}_{4}$ & $\begin{array}{l}\text { Ikan licin, berlendir, air sedikit } \\
\text { kental, agak keputihan/Slippery } \\
\text { skin, slightly whitish and } \\
\text { viscous solution }\end{array}$ & $\begin{array}{l}\text { Ikan mengalami peru } \\
\text { bahan warna sedikit/ } \\
\text { Slightly discoloured }\end{array}$ & $\begin{array}{l}\text { Kenampakan, utuh, kurang bercahaya, } \\
\text { bau segar harum, tekstur padat kurang } \\
\text { kompak dan rasa sedikit kurang gurih, } \\
\text { agak hambar/Neat appearance, } \\
\text { undamage, less shiny, freshy odor, } \\
\text { less compact and slightly tasteless }\end{array}$ \\
\hline $\mathrm{Ca}(\mathrm{OH})_{2}$ & $\begin{array}{l}\text { Ikan licin, berlendir, air } \\
\text { perendam berwarna } \\
\text { putih/Slipperry skin, slimy } \\
\text { slightly whitish and viscous } \\
\text { solution }\end{array}$ & $\begin{array}{l}\text { Ikan tidak mengalami } \\
\text { perubahan warna/ } \\
\text { No discolouration }\end{array}$ & $\begin{array}{l}\text { Kenampakan agak kusam, permukaan } \\
\text { pecah pecah, bau kurang harum, } \\
\text { sedikit bau basa, tekstur kurang } \\
\text { kompak agak lembek dan rasa kurang } \\
\text { gurih, agak hambar/ Sligtly dull } \\
\text { appereance, less freshy, less compact, } \\
\text { slightly soft tasteless }\end{array}$ \\
\hline STTP & $\begin{array}{l}\text { Ikan licin, berlendir, air } \\
\text { perendam sedikit berwarna } \\
\text { kemerah-merahan/Slipperry } \\
\text { skin, slimy reddish solution }\end{array}$ & $\begin{array}{l}\text { Ikan mengalami } \\
\text { perubahan warna/ } \\
\text { Discolouration }\end{array}$ & $\begin{array}{l}\text { Kenampakan rapi utuh, kurang } \\
\text { bercahaya, bau segar harum, tekstur } \\
\text { padat, kurang kompak dan rasa enak } \\
\text { sedikit kurang gurih/Neat appearance, } \\
\text { less shiny, freshy odor, less compact, } \\
\text { tasteless }\end{array}$ \\
\hline
\end{tabular}


ikan dalam larutan tawas, menyebabkan ikan tidak berlendir dan permukaan ikan tidak licin dibandingkan dengan perendaman dalam garam kimia lainnya ( $\mathrm{Ca}$ $\mathrm{Cl}_{2}, \mathrm{Ca} \mathrm{SO}_{4}, \mathrm{Ca}(\mathrm{OH})_{2}$, dan STPP).

Hal serupa juga dikemukakan oleh Nurrahman \& Isworo (2005) dalam penelitiannya terhadap ikan tongkol yang direndam dalam larutan tawas, menghasilkan ikan dengan tekstur yang lebih kompak dan keras dengan permukaan kulit yang lebih keset. Pengamatan secara visual menunjukkan bahwa selama perendaman terjadi penggumpalan lendir, sehingga lendir pada permukaan kulit terlepas dan ikan menjadi tidak licin (keset) yang tidak terjadi pada garam lainnya. Menurut Winarno (2004) tawas dalam larutan cenderung untuk menurunkan keasaman, karena adanya ion sulfat dalam tawas yang memberikan suasana larutan menjadi asam. Sementara lendir merupakan senyawa mucopolisakarida yang bila terkena asam dapat mengalami penggumpalan. Perendaman dalam tawas dan STPP menyebabkan darah dalam daging ikan tercuci, yang terlihat dari warna merah pada air yang digunakan untuk merendam ikan. Pengeluaran darah ini akan menyebabkan ikan tidak berbau amis dan tidak mudah busuk. Hemoglobin dalam daging ikan mengandung zat besi dalam bentuk ferri sulfat yang akan mengkatalisis terjadinya oksidasi lemak, menjadi asam lemak bebas yang apabila berikatan dengan senyawa lain menyebabkan terjadinya bau amis (Tanaka \& Osako, 2009).

Pengamatan secara visual menunjukkan bahwa perendaman dalam larutan tawas dan STPP menyebabkan terjadinya diskolorisasi lebih nyata dibandingkan dengan garam lainnya $\left(\mathrm{Ca} \mathrm{Cl}_{2}, \mathrm{Ca} \mathrm{SO}_{4}\right.$, $\mathrm{Ca}(\mathrm{OH})_{2}$ ). Pada umumnya pigmen peka terhadap perubahan $\mathrm{pH}$ (asam) dan perubahan panas, (Winarno, 2004) sehingga sifat asam pada larutan tawas menyebakabkan perubahan warna karena oksidasi pigmen melanin pada kulit ikan lele yang berwarna hitam, sehingga warnanya menjadi lebih pucat. Lele merupakan ikan yang tidak bersisik dan kulit lele cukup tebal yang tersusun dari kolagen. Kolagen merupakan protein yang bersifat larut dalam air panas, dan membentuk suatu matrik seperti gum/lendir. Adanya matrik seperti lendir ini menyebabkan kenampakan pindang lele kurang menarik, sehingga untuk menghilangkan matrik seperti lendir tersebut maka setelah dipindang lele dipanaskan kembali dalam oven pada suhu $60-70^{\circ} \mathrm{C}$. Di samping itu pemanasan kembali juga untuk mengurangi kadar air sehingga menghasilkan tekstur pindang ikan lele yang lebih baik

Dari pengamatan sensori secara deskriptif terhadap pindang ikan lele menunjukkan bahwa perendaman dalam larutan tawas menghasilkan kenampakan yang lebih baik, bau yang segar dan harum serta rasa yang enak dan gurih dibandingkan dengan garam lainnya. Larutan tawas mempunyai keunggulan dapat menghilangkan lendir dan darah serta menyebabkan perubahan warna, sehingga warna hitam kulit lele menjadi sedikit lebih pucat, setelah direndam. Perubahan warna menyebabkan afinitas warna kuning kunyit dari bumbu lebih tajam, sehingga wana pindang lebih kekuningan. Oleh karena itu garam terbaik yang digunakan dalam penelitian selanjutnya adalah tawas $\left(\mathrm{Al}_{2} \mathrm{SO}_{4}\right)$, di samping itu tawas harganya lebih murah dan mudah didapat dibandingkan dengan garam lainnya.

\section{Penelitian Utama}

\section{Analisis kimia ikan lele segar}

Lele yang digunakan dalam penelitian ini adalah lele segar yang berasal dari lele hidup yang dimatikan sebelum diolah, sehingga ikan masih sangat segar dengan kandungan TVB 2,47 mg/N\%, pH netral sekitar 6,62 dan jumlah bakteri 3,13 × 10 $\mathrm{sel} / \mathrm{g}\left(<10^{5}\right.$ sel/g). Ikan lele tergolong ikan yang mempunyai kadar air cukup tinggi yaitu sebesar 75,18 \pm 0,95\% kadar protein dan lemak sedang yaitu berturut turut 17,98 $\pm 0,17 \%$ dan $4,43 \pm 1,82 \%$ dan kadar abu 1,32 \pm $0,10 \%$.

\section{Analisis Proksimat Pindang Ikan Lele}

Hasil pengamatan analisis proksimat pindang ikan lele pada berbagai perlakuan dapat dilihat pada Tabel 2. Hasil analisis statistik menunjukkan bahwa perlakuan perendaman (cuka dan tawas), konsentrasi bumbu serta interaksi keduanya hanya berpengaruh terhadap kadar abu dan kadar protein sedangkan kadar air dan lemak tidak dipengaruhui oleh perlakuan yang diberikan.

Kadar air pindang ikan lele sebelum dipanaskan dengan menggunakan oven sebesar 72,3-73,5\%. Kadar ini tidak jauh berbeda jika lele diolah dengan menggunakan microwave atau dioven yaitu sebesar 72,7\% (Ersoy \& Ozeren, 2008). Kadar air pindang ikan lele yang diperoleh masih di atas standar mutu pindang untuk kadar air yang dikeluarkan oleh SNI 2009 yaitu maksimal 60\%. Oleh karena itu untuk mengurangi kadar airnya, pindang dipanaskan kembali dalam oven, selama 1 jam pada suhu $60-70^{\circ} \mathrm{C}$. Dengan penamasan kembali dalam oven diperoleh kadar air pindang ikan lele yang berkisar antara 64,04-65,87\%, kadar ini tidak jauh berbeda dengan kadar air pindang ikan tongkol hasil penelitian Subaryono et al. (2004) sebesar 64,19-65,17\%, ikan layang sebesar 68,82\% (Irianto \& Pratiwi, 2009) dan ikan lisong yang berkisar antara 56,69-66,45\% (Dwiyitno, 2005). Pemanasan kembali dalam oven 
Tabel 2. Analisis proksimat pindang ikan lele pada berbagai perlakuan Table 2. Proximate analysis boiled salted catfish at various treatments

\begin{tabular}{lcccc}
\hline $\begin{array}{c}\text { Perlakuan/ } \\
\text { Treatment }\end{array}$ & $\begin{array}{c}\text { Kadar airl } \\
\text { Water Content }\end{array}$ & $\begin{array}{c}\text { Kadar Abul } \\
\text { Ash content }\end{array}$ (\%) & $\begin{array}{c}\text { Kadar Protein/ } \\
\text { Protein Content (\%) }\end{array}$ & $\begin{array}{c}\text { Kadar Lemakl } \\
\text { Fat Content (\%) }\end{array}$ \\
\hline C0 & $64.36 \pm 1.62^{\mathrm{a}}$ & $3.43 \pm 0.16^{\mathrm{a}}$ & $23.48 \pm 0.68^{\mathrm{a}}$ & $8.44 \pm 1.0^{\mathrm{a}}$ \\
T0 & $64.61 \pm 1.53^{\mathrm{a}}$ & $3.26 \pm 0.37^{\mathrm{a}}$ & $21.89 \pm 0.71^{\mathrm{b}}$ & $9.36 \pm 1.57^{\mathrm{a}}$ \\
C5 & $64.04 \pm 1.24^{\mathrm{a}}$ & $3.33 \pm 0.49^{\mathrm{a}}$ & $23.53 \pm 1.94^{\mathrm{a}}$ & $9.80 \pm 2.23^{\mathrm{a}}$ \\
T5 & $65.64 \pm 0.48^{\mathrm{a}}$ & $3.06 \pm 0.02^{\mathrm{a}}$ & $21.16 \pm 0.72^{\mathrm{b}}$ & $9.86 \pm 0.88^{\mathrm{a}}$ \\
C7 & $65.82 \pm 0.31^{\mathrm{a}}$ & $3.70 \pm 0.02^{\mathrm{b}}$ & $21.51 \pm 0.44^{\mathrm{bc}}$ & $7.59 \pm 0.20^{\mathrm{a}}$ \\
T7 & $64.91 \pm 1.85^{\mathrm{a}}$ & $3.71 \pm 0.18^{\mathrm{b}}$ & $20.83 \pm 1.29^{\mathrm{bc}}$ & $9.14 \pm 1.62^{\mathrm{a}}$ \\
C10 & $64.93 \pm 0.93^{\mathrm{a}}$ & $3.59 \pm 0.3^{\mathrm{b}}$ & $22.16 \pm 0.96^{\mathrm{ac}}$ & $9.63 \pm 0.96^{\mathrm{a}}$ \\
T10 & $64.82 \pm 1.03^{\mathrm{a}}$ & $3.77 \pm 0.17^{\mathrm{b}}$ & $21.71 \pm 1.73^{\mathrm{bc}}$ & $8.54 \pm 1.79^{\mathrm{a}}$ \\
\hline
\end{tabular}

Keterangan/Note :

C0 : Perendaman dalam cuka dan bumbu 0\%/Dipping in acetic acid and spices 0\%

T0 : Perendaman dalam tawas dan bumbu 0\%/Dipping in alum and spices 0\%

C5 : Perendaman dalam cuka dan bumbu 5\%/Dipping in acetic acid and spices 5\%

T5 : Perendaman dalam tawas dan bumbu 5\% /Dipping in alum and spices 5\%

C7 : Perendaman dalam cuka dan bumbu 7,5\%/Dipping in acetic acid and spices 7.5\%

T7 : Perendaman dalam tawas dan bumbu 7,5\%/Dipping in alum and spices $7.5 \%$

C10 : Perendaman dalam cuka dan bumbu 10\%/Dipping in acetic acid and spices 10\%

T10 : Perendaman dalam tawas dan bumbu 10\%/Dipping in alum and spices 10\%

selain untuk menurunkan kadar air juga berfungsi untuk menghilangkan matrik seperti lendir sehingga kenampakan pindang lebih menarik. Pengurangan kadar air ini akan berpengaruh pada daya awet serta tekstur pindang ikan lele yang dihasilkan. Hal ini disebabkan kadar air bahan pangan sangat penting dalam menentukan daya awet suatu produk. Kadar air juga berpengaruh terhadap sifat-sifat fisik (organoleptik), sifat kimia, dan pembusukan oleh mikroorganisme (Buckle et al., 1987).

Kadar abu pindang ikan lele berkisar antara 3,05$3,76 \%$. Nilai tersebut menunjukkan adanya mineral yang terdapat pada pindang ikan lele. Ikan lele merupakan sumber mineral kalium yang jumlahnya cukup tinggi yaitu berkisar antara 1817-2770 mg/kg (Erzoy \& Ozeren, 2008). Hasil analisis statistik menunjukkan bahwa perlakuan perendaman (cuka dan tawas) serta keduanya tidak berpengaruh terhadap kadar abu $(p>0,05)$. Sedangkan perlakuan konsentrasi bumbu yang digunakan berpengaruh nyata terhadap kadar abu pindang lele yang dihasilkan $(p<0,05)$. Kadar abu dalam produk pangan adalah mineral atau zat organik yang tidak menguap atau sisa dari proses pembakaran. Oleh karena itu dalam penelitian ini semakin banyak konsentrasi bumbu yang diberikan semakin banyak garam dan mineral dari bumbu yang tidak terbakar dalam proses pengabuan. Lele yang diolah dengan direbus, dipanggang, dimasak dalam microwave atau digoreng tanpa bumbu kadar abunya berkisar antara 0,831,15\% (Erzoy \& Ozeren, 2008).

Kadar protein pindang lele berkisar 20,83-23,84\%. Kadar protein ini tidak jauh berbeda dengan kadar protein ikan lele yang diolah dengan microwave, dibakar, di oven atau digoreng yang berkisar antara 19,5-21,8\% (Erzoy \& Ozeren, 2008). Kadar protein pindang dipengaruhi oleh spesies ikan yang digunakan sebagai bahan baku. Pindang ikan lele mengandung kadar protein yang lebih rendah dibandingkan dengan ikan layang (26,52\%) (Ariyani \& Yenny 2008) serta salmon yang diolah dengan perebusan $(25,28 \%)$ dan dimasak menggunakan microwave (32,07\%) (Unusan, 2007). Nilai rata rata kadar protein pindang lele yang direndam dalam larutan tawas lebih rendah dan berbeda nyata $(p<0,05)$ bila dibandingkan dengan kadar protein ikan lele yang direndam dalam larutan cuka. Demikian juga semakin banyak konsentrasi bumbu yang diberikan semakin rendah kadar proteinnya. Hasil uji Duncan menunjukkan bahwa kadar protein pindang yang diolah dengan konsentrasi bumbu $0 \%$ dan $5 \%$ berbeda nyata dengan kadar protein pindang ikan lele yang diberi bumbu $7,5 \%$ dan $10 \%$. Rendahnya kadar protein pindang yang direndam dalam tawas dan bumbu dengan konsentrasi tinggi disebabkan karena terlarutnya protein larut garam seperti aktin, miosin, troponin, aktinin. Hal ini sejalan dengan hasil penelitian 
Nurrahman \& Isworo ( 2005) mengenai peran tawas terhadap penguraian protein ikan tongkol. Umumnya perendaman ikan dalam larutan tawas berpengaruh terhadap penurunan kadar nitrogen terlarut, kadar asam amino, dan kadar protein terlarut pada ikan yang direndam. Demikian juga semakin besar konsentrasi bumbu semakin besar konsentrasi garam yang diberikan sehingga semakin banyak protein yang terlarut, sehingga berpengaruh terhadap menurunnya kandungan protein pada pindang ikan lele.

Kadar lemak ikan pindang ikan lele berkisar antara 8,44-9,86\%, kandungan lemak yang cukup tinggi ini menyebabkan rasa pindang ikan lele yang dihasilkan menjadi gurih. Apabila dilihat dan dinilai rata-rata kadar lemak pindang ikan lele, perlakuan perendaman (cuka dan tawas) tidak berpengaruh nyata terhadap kadar lemak pindang ikan lele yang dihasilkan, demikian juga konsentrasi bumbu yang diberikan.

\section{Nilai $\mathrm{pH}$}

Nilai rata-rata $\mathrm{pH}$ pindang ikan lele dapat dilihat pada Gambar 2. pH pindang ikan lele pada berbagai perlakuan mendekati netral yaitu berkisar antara 6,36-6,52. Hasil analisis statistik menunjukkan bahwa perlakuan perendaman tidak berbeda nyata terhadap pindang ikan lele yang dihasilkan. Rata-rata nilai $\mathrm{pH}$ pindang ikan lele yang direndam dalam larutan tawas sebesar 6,43 sedangkan pindang ikan lele yang direndam dalam larutan cuka sebesar 6,50. Sedangkan perlakuan konsentrasi bumbu yang diberikan berpengaruh terhadap nilai $\mathrm{pH}$ pindang ikan lele yang dihasilkan $(p<0.05)$. Terlihat bahwa semakin tinggi konsentrasi bumbu yang diberikan semakin menurun nilai pH pindang ikan lele yang dihasilkan. Nilai $\mathrm{pH}$ pindang ikan lele yang direndam dalam pasta bumbu $5 \%$, tidak berbeda nyata dengan nilai $\mathrm{pH}$ pindang ikan lele tanpa perendaman bumbu. Penggunaan pasta bumbu dengan konsentrasi sebesar $5 \%$ belum berpengaruh terhadap nilai $\mathrm{pH}$ pindang yang dihasilkan, sedangkan perendaman bumbu dengan konsentrasi $7,5 \%$ dan $10 \%$ baru berpengaruh terhadap menurunnya nilai pindang lele yang dihasilkan. Dalam penelitian ini bumbu yang digunakan mengandung bawang putih yang mengandung senyawa alisin dan lengkuas yang bersifat asam (Yuliawati, 2004). Hal ini menyebabkan semakin tinggi konsentrasi bumbu yang digunakan semakin bersifat asam, sehingga menurunkan nilai $\mathrm{pH}$ pindang yang dihasilkan. Pada pindang yang direndam dalam konsentrasi bumbu 7,5 dan $10 \%$, dan direndam dalam larutan tawas menyebabkan menurunnya nilai $\mathrm{pH}$ yang lebih rendah. Tawas bila dilarutkan dalam air akan membebaskan ion $\mathrm{H}^{+}$ dengan kadar yang tinggi serta ion alumunium $\left(\mathrm{Al}^{+++}\right)$. Ion Alumunium yang bersifat amfoter bergantung pada suasana lingkungan yang mempengaruhinya. Karena suasananya asam maka alumunium juga bersifat asam sehingga $\mathrm{pH}$ larutan menjadi turun (Hidayati, 2012).

\section{Kandungan bakteri pindang lele}

Hasil analisis angka lempeng total bakteri menunjukkan bahwa perlakuan perendaman dan konsentrasi bumbu tidak memberikan pengaruh terhadap kandungan jumlah bakteri pindang ikan lele yang dihasilkan. Semua pindang ikan lele yang dianalisis kandungan bakterinya $<25 \times 10^{1} \mathrm{sel} / \mathrm{g}$ kecuali pada perlakuan perendaman cuka tanpa bumbu, sedangkan analisis terhadap $E$ coli dan Salmonella menunjukkan hasil yang negatif seperti

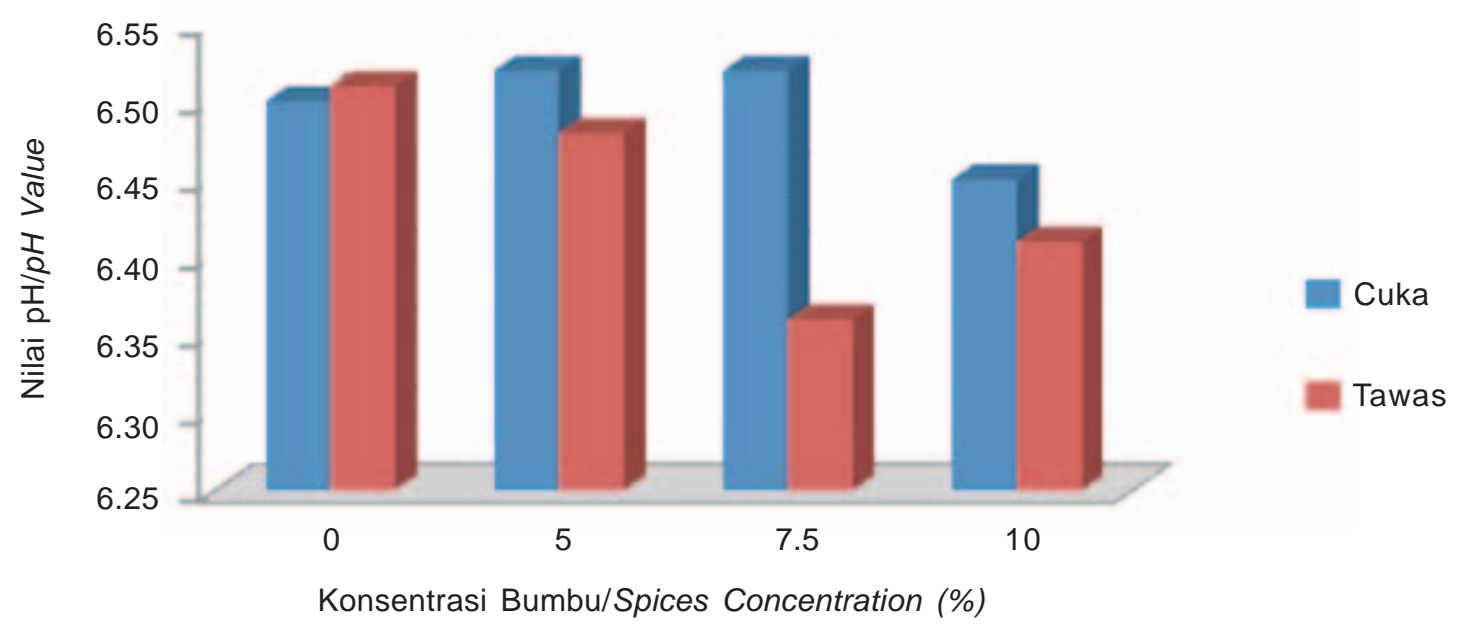

Gambar 2. Histogram nilai rata rata $\mathrm{pH}$ pindang ikan lele pada berbagai perlakukan.

Figure 2. Histogram of $\mathrm{pH}$ value of boiled salted catfish at various treatments. 
Tabel 3. Hasil analisis mikroba pindang ikan lele pada berbagai perlakuan

Table 3. Result of microbe analysis of boiled salted cat fish at various treatments

\begin{tabular}{cccc}
\hline $\begin{array}{c}\text { Perlakuan/ } \\
\text { Treatments }\end{array}$ & $\begin{array}{c}\text { Angka Lempeng Totall } \\
\text { Total Plate Count }(\text { sel/g) }\end{array}$ & E coli & Salmonela \\
\hline C0 & $2.06 \times 10^{2}$ & Negatif & Negatif \\
T0 & $<25 \times 10^{1}$ & Negatif & Negatif \\
C5 & $<25 \times 10^{1}$ & Negatif & Negatif \\
T5 & $<25 \times 10^{1}$ & Negatif & Negatif \\
C7 & $<25 \times 10^{1}$ & Negatif & Negatif \\
T7 & $<25 \times 10^{1}$ & Negatif & Negatif \\
C10 & $<25 \times 10^{1}$ & Negatif & Negatif \\
T10 & $<25 \times 10^{1}$ & Negatif & Negatif \\
\hline
\end{tabular}

Keterangan/Note :

CO : Perendaman dalam cuka dan bumbu 0\%/Dipping in acetic acid and spices 0\%

T0 : Perendaman dalam tawas dan bumbu 0\%/Dipping in alum and spices 0\%

C5 : Perendaman dalam cuka dan bumbu 5\%/Dipping in acetic acid and spices 5\%

T5 : Perendaman dalam tawas dan bumbu 5\% IDipping in alum and spices 5\%

C7 : Perendaman dalam cuka dan bumbu 7,5\%/Dipping in acetic acid and spices $7.5 \%$

T7 : Perendaman dalam tawas dan bumbu 7,5\%/Dipping in alum and spices $7.5 \%$

C10 : Perendaman dalam cuka dan bumbu 10\%/Dipping in acetic acid and spices 10\%

T10 : Perendaman dalam tawas dan bumbu 10\%/Dipping in alum and spices 10\%

terlihat pada Tabel 3. Pemanasan menyebabkan reduksi jumlah bakteri ikan lele dari $10^{3} \mathrm{sel} / \mathrm{g}$ dalam kondisi segar menjadi $10^{1} \mathrm{sel} / \mathrm{g}$ setelah jadi pindang lele. Sedangkan E. coli dan Salmonella merupakan bakteri yang bersifat gram negatif dan bersifat pathogen. Bakteri tersebut mempunyai ketahanan panas dengan nilai z sebesar $52,91^{\circ} \mathrm{C}$ (Mazzota \& Doyle, 2000). Sementara dalam penelitian ini pemanasan dilakukan pada suhu $94-95^{\circ} \mathrm{C}$ selama 1 jam, yang menyebabkan rusaknya dinding sel serta cytoplasmik (Rusell, 2003), sehingga menyebabkan kematian bakteri E. coli dan Salmonella.

\section{Sifat sensori pindang ikan lele}

Pengamatan sifat sensori dilakukan untuk menentukan diterima atau ditolaknya produk pindang ikan lele oleh panelis, sehingga dapat dijadikan acuan apakah pindang ikan lele dapat diterima konsumen apabila dipasarkan. Pengujian dilakukan dengan menggunakan uji hedonik dan uji skor.

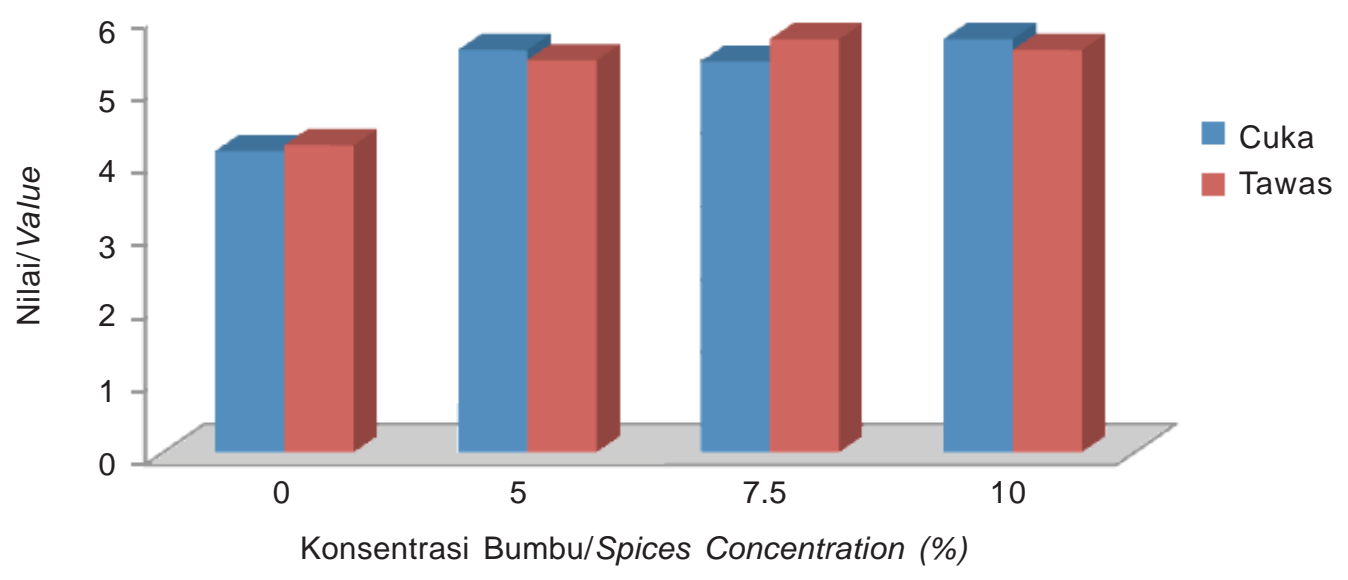

Gambar 3. Histogram nilai rata-rata uji hedonik pindang ikan lele pada berbagai perlakuan.

Figure 3. Histogram of hedonic score boiled salted catfish at various treatments. 


\section{Uji Hedonik}

Hasil pengamatan uji kesukaan pindang ikan lele dengan menggunakan skala hedonik 1-7 dapat dilihat pada Gambar 3. Gambar 3 menunjukkan bahwa perlakuan perendaman (cuka dan tawas) tidak memberikan tingkat kesukaan yang berbeda nyata terhadap pindang lele yang dihasilkan $(p>0.05)$. Sedangkan penambahan bumbu yang diberikan memberikan pengaruh yang berbeda nyata, terhadap kesukaan panelis terhadap pindang lele yang dihasilkan, namun konsentrasi bumbu tidak berpengaruh terhadap kesukaan panelis terhadap pindang lele secara nyata. Dalam penelitian ini penambahan bumbu selain dapat meningkatkan cita rasa, juga memberikan kenampakan pindang ikan lele yang lebih menarik. Penggunaan kunyit sebagai salah satu bumbu selain menghilangkan bau amis, juga memberikan warna kuning pada bagian perut lele, sehingga warna pindang lele agak kekuningan. Hal yang menarik dalam penelitian ini adalah penambahan bumbu juga menyebabkan tidak lengketnya permukaan antar produk, sehingga produk mudah dipisahkan antara satu dengan yang lainnya. Lele merupakan ikan yang tidak bersisik, yang komponen utama penyusunnya adalah kolagen. Menurut Katili (2009) jika kolagen dipanaskan maka strukturnya menjadi rusak secara permanen dan menghasilkan gelatin. Sejumlah besar rantai samping yang bersifat hidroksil dalam gelatin akan membentuk gel yang bersifat lengket satu sama lainnya. Dengan adanya bumbu, gelatin akan bercampur dengan bumbu dan ketika dingin akan menjendal dan membentuk lapisan tipis. Adanya lapisan tipis tersebut menyebabkan pindang ikan tidak lengket dan kulitnya tidak rusak ketika dipisahkan.

\section{Uji skor}

Hasil uji skor pindang ikan lele terhadap kenampakan, bau, rasa dan tekstur dapat dilihat pada Gambar 4. Hasil uji Kruskal Wallis pindang ikan lele yang diberi perlakuan perendaman (cuka dan tawas) serta pemberian bumbu dengan konsentrasi yang berbeda memberikan pengaruh yang tidak berbeda nyata terhadap kenampakan pindang ikan lele yang dihasilkan. Namun demikian panelis cenderung memberikan nilai rata rata untuk kenampakan pindang yang direndam dalam larutan tawas lebih tinggi $(8,11)$ dibandingkan dengan pindang ikan lele yang direndam dalam larutan cuka $(7,92)$, walaupun secara statistik kedua nilai tersebut tidak berbeba nyata. Penilaian secara organoleptik merupakan penilaian yang sifatnya subyektif dan memungkinkan tingginya
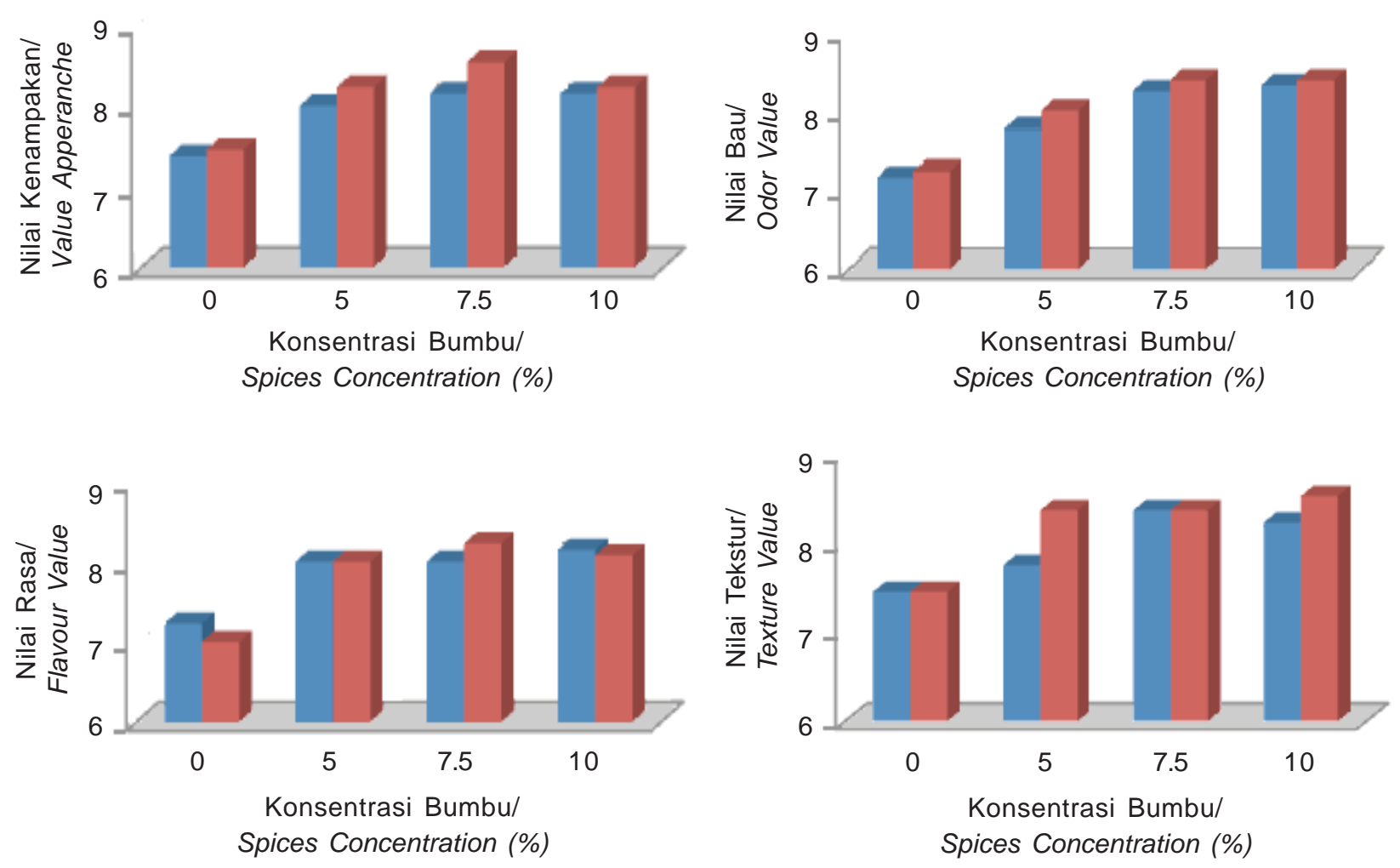

Gambar 4. Uji skor terhadap kenampakan, bau, rasa dan tekstur pindang ikan lele.

Figure 4. Scoring test of appearance, odor, taste and texture of boiled salted catfish. 
standar deviasi sehingga ketika dianalis secara statistik hasilnya tidak berbeda nyata.

Kecenderungan panelis memberikan nilai yang lebih tinggi pada pindang yang diberi perlakuan perendaman dalam larutan tawas disebabkan karena pindang lele yang dihasilkan berwarna lebih kuning dibandingkan dengan pindang lele yang direndam dalam larutan cuka.

Demikian juga pindang ikan lele yang tidak diberi bumbu (0\%) mempunyai nilai kenampakan yang lebih rendah dibandingkan dengan pindang lele yang diberi bumbu. Panelis memberikan nilai kenampakan pindang lele yang tidak diberi bumbu sebesar 7,42 sedangkan pindang ikan lele yang diberi bumbu nilai rata-ratanya di atas 8,0 yang berarti penambahan bumbu menghasilkan kenampakan pindang ikan lele yang lebih rapi, permukaan tidak pecah-pecah dan warna yang lebih menarik. Panelis memberikan nilai tertinggi pada pindang ikan lele yang direndam dalam larutan cuka dan diberi bumbu dengan konsentrasi sebanyak 7,5\%. Pemberian bumbu yang terlalu banyak justru akan menurunkan penilaian panelis terhadap kenampakan pindang yang dihasilkan. Karena kelebihan bumbu yang diberikan akan menyebabkan kenampakan pindang kurang rapi. Penggunaan bumbu $7,5 \%$ dari berat ikan tidak menyisakan bumbu yang digunakan, sedangkan konsentrasi $10 \%$ dari berat bumbu menghasilkan jumlah bumbu yang berlebih yang menempel pada permukaan kulit lele sehingga kenampakan pindang sedikit kurang rapi.

Hasil penilaian panelis terhadap bau pindang ikan lele berkisar antara 7,15 ( segar-kurang harum )- 8,31 (segar-harum). Hasil uji Kruskal Wallis menunjukkan bahwa perlakuan perendaman serta perbedaan konsentrasi bumbu memberikan pengaruh yang berbeda nyata terhadap bau pindang ikan lele yang dihasilkan. Panelis memberikan rata-rata nilai bau pindang yang direndam dalam larutan tawas sebesar 8,0 lebih tinggi dibandingkan dengan nilai bau ikan pindang dalam larutan cuka 7,86. Perendaman dalam larutan tawas menyebabkan larutnya sebagian darah pada ikan (Tabel 1), sehingga produk yang diolah berbau lebih segar dan harum. Bumbu pada pindang ikan lele menyebabkan peningkatan nilai bau secara signifikan terhadap bau pindang yang diperoleh yaitu 7,19 (segar, kurang harum) pada pindang yang diolah tanpa bumbu (0\%) naik menjadi 8,34 (segar, harum) jika diberi bumbu dengan konsentrasi 10\%. Semakin tinggi konsentrasi bumbu yang diberikan akan menghasilkan bau yang lebih harum yang berasal dari minyak atsiri yang terkandung dalam bumbu seperti lengkuas, jahe, kunyit dan bawang putih. Penambahan bumbu selain dapat menghasilkan aroma yang khas pada pindang juga dapat meningkatkan daya awet pindang berbumbu (Yuliawati, 2004)

Uji skor terhadap rasa menunjukkan bahwa perlakuan perendaman cuka dan tawas tidak memberikan pengaruh terhadap rasa. Pindang yang diolah dengan direndam dalam larutan cuka mempunyai nilai rasa sebesar 7,84 tidak berbeda dengan pindang lele yang diolah dengan tawas yaitu sebesar 7,82. Namun perlakuan konsentrasi bumbu menyebabkan peningkatan terhadap rasa pindang secara signifikan. Pindang yang diolah tanpa bumbu hanya mempunyai nilai sebesar 7,11 namun ketika diberi bumbu dengan konsentrasi 5\% nilai rasa meningkat jadi 8,0 sedangkan pemberian bumbu dengan konsentrasi 7,5\% dan 10\% memberikan nilai rasa yang sama yaitu 8,11 . Rasa menunjang peranan penting dari penerimaan suatu produk oleh konsumen. Oleh karena itu dalam pengolahan pindang lele penambahan bumbu mutlak diperlukan, selain dapat mempengaruhi kenampakan, bumbu juga berpengaruh terhadap cita rasa pindang yang dihasilkan.

Uji skor terhadap tekstur menunjukkan bahwa panelis memberikan nilai rata-rata tekstur pindang ikan lele berkisar antara 7,23 (padat kurang kompak) $-7,77$ (padat kompak). Hasil uji Kruskal Wallis menunjukkan bahwa perlakuan perendaman bahan baku dalam larutan tawas dan cuka tidak berpengaruh terhadap tekstur pindang ikan lele yang dihasilkan. Hal ini berbeda dengan hasil penelitian Nurrahman \& Isworo (2002), terhadap ikan tongkol yang memberikan tekstur daging ikan lebih kompak, memperpanjang umur simpan ikan, memberi warna ikan asap yang lebih menarik serta menghilangkan bau amis pada ikan. Perbedaan tersebut disebabkan karena perbedaan konsentrasi tawas yang digunakan pada penelitian ini konsentrasi tawas yang digunakan sebesar 0,2\%, sedangkan pada penelitian Nurrahman \& Isworo (2002) konsentrasi tawas yang digunakan untuk perendaman ikan tongkol sebesar $1 \%$. Hal ini menunjukkan bahwa konsentasi 0,2\% belum mampu meningkatkan tekstur ikan lele secara nyata. Perendaman ikan dengan konsentrasi tawas 1\% akan menyebabkan denaturasi protein. Denaturasi akan menyebabkan perubahan struktur protein, yang berakibat hilangnya struktur sekunder, tersier dan kuartier, namun belum menyebabkan pemutusan ikatan peptida pada struktur primernya (Wijanarko, 2008). Sedangkan menurut Fenema (2007) denaturasi akan menyebabkan lapisan molekul bagian dalam yang bersifat hidrofobik akan keluar dan bagian luar yang bersifat hidrofilik akan ke dalam. Rusaknya struktur protein tersebut akan menyebabkan kemampuan sifat fungsional protein untuk menyerap 
air menjadi menurun, sehingga tekstur ikan menjadi lebih padat.

Pemberian bumbu mempengaruhi penilaian panelis terhadap tekstur pindang yang dihasilkan. Rata-rata panelis lebih menyukai tekstur pindang yang diberi bumbu $(7,38-7,7)$ dibandingkan pindang tanpa bumbu $(7,23)$. Pemberian bumbu meningkatkan penilaian panelis terhadap tekstur pindang yang dihasilkan, namun konsentrasi bumbu 5; 7,5; dan 10\% tidak berpengaruh terhadap nilai tekstur pindang ikan lele yang dihasilkan. Peningkatan tekstur pada pindang yang diberi bumbu ini disebabkan karena garam dan gula pada bumbu pindang yang diberikan. Garam dapat menurunkan air bebas dan meningkatkan daya ikat air oleh daging ikan sehingga mempengaruhi tingkat kekerasan produk (Suparno, 1998 dalam Ratnasari 2002). Sedangkan gula jika dipanaskan akan terjadi karamelisasi, dan menjadi kaku ketika didinginkan, sehingga berpengaruh terhadap meningkatnya tekstur pindang yang diberikan. Meningkatnya nilai tekstur karena penambahan gula sama dengan hasil penelitian Yuliawati (2004) pada pindang manis ikan mas.

\section{KESIMPULAN}

Tawas merupakan garam yang terbaik untuk meningkatkan kenampakan, bau dan tekstur pada pindang lele dibandingkan dengan garam lainnya.

Pengolahan pindang ikan lele dengan perlakuan perendaman dalam larutan tawas dan cuka serta perendaman bumbu hanya berpengaruh terhadap kadar abu, protein dan pH pindang ikan lele yang dihasilkan, tetapi tidak berpengaruh terhadap kadar air, lemak, serta cemaran mikroba pindang yang dihasilkan.

Pengolahan pindang ikan lele dengan menggunakan bumbu menghasilkan pindang yang secara sensori lebih disukai panelis dibandingkan dengan pindang ikan lele tanpa penambahan bumbu, karena dapat menghindari terjadinya kelengketan permukaan antar produk. Pindang ikan lele yang diberi perlakuan perendaman dalam larutan tawas dan diberi bumbu dengan konsentrasi 7,5\% menghasilkan pindang yang paling baik dibandingkan dengan perlakuan lainnya.

\section{DAFTAR PUSTAKA}

Anonim. 2012. KKP menargetkan produksi ikan nila naik pada 2011 naik 36,26\%. Harian Kontan. Senin 23 Januari 2012.

Ariyani, F. dan Yennie, Y. 2008. Pengawetan pindang ikan layang (Decapturus nusselli) menggunakan khitosan. Journal Pascapanen dan Bioteknologi Kelautan dan Perikanan. 3(2): 130-146.

Buckle, K.A., Edwards, R.A., Fleet, G.H., and Wooton, M. 1987. Ilmu Pangan. Terjemahan Hari Purnomo. Universitas Indonesia. Press Jakarta.

Badan Standardisasi Nasional (BSN). 2006a . Cara Uji Kimia pada Produk Perikanan. SNI -01.2354 - 2006 Standar Nasional Indonesia.

Badan Standardisasi Nasional (BSN). 2006 . Cara Uji Mikrobiologi pada Produk Perikanan. SNI -01.2332 - 2006 Standar Nasional Indonesia.

Badan Standardisasi Nasional (BSN). 2006 . Petunjuk Pengujian Organoleptik/Sensori. SNI -01-23462006. Badan Standardisasi Nasional (BSN).

Dwiyitno, Ariyani, F., Kusmiyati, T., dan Harmita. 2005. Perlakuan perendaman dalam larutan asam untuk menghambat perkembangan histamin pada ikan lisong (Scomber austrafasicus CV). J. Penel Perikanan Indonesia. 11(8): 1-8.

Ersoy, B. and Ozeren, A. 2008. The effect of cooking methods on mineral and vitamin contents of African catfish (Clarias gariepinus). Food Chemistry. 115: 419-423.

Fallah, B. 2012. Industri pengolahan ikan pindang kekurangan bahan baku. http://www.tempo.co/read/ news/2012/01/16/090377578/Indonesia kekurangan -ikan pindang. Diakses pada tanggal 3 Juni 2012.

Fenema, O. R. 2007. Food Chemistry. Fourth edition TF CRC 1168 p.

Haribi, R. dan Yusrin. 2004. Konsentrasi aluminium pada ikan asap yang direndam dalam larutan tawas. Http Jurnal Unimus. Ac.ld. 280-296. Diakses pada tanggal 22 Mei 2012.

Hidayati, N. 2012. Tawas sebagai koagulan. http:// blogpengajarankimia blogspot.com/2012/05/tawassebagai-koagulan Diakses pada tanggal 9 Mei 2012.

Irianto, H.E. and Pratiwi, Y.S. 2009. Chemical and organoleptical changes in pindang cue during storage at ambient and chill temperatures. Jurnal Pascapanen dan Bioteknologi Kelautan dan Perikanan. Edisi khusus dalam rangka WOC 2009. 4: 62-67.

Katili, A.S. 2009. Struktur dan fungsi protein kolagen. Jurnal Pelangi IImu. 2(5): 19-29.

Kvech, S. and Edwards, M. 2002. Solubility controls on aluminum in drinking water at relatively low and high pH". WATER RESEARCH. 36(17): 4356-436

Kotacepe, D., Turan, H., Taskaya, G., Kaya, Y., Erden, R. and Erdogdu, F. 2011. Effect of cooking methods on the proximate composition of Black Sea Anchovy (Engraulis encrasicolus. L). GIDA. 36(2): 71-75.

Mazzota, S. and Doyle, M.E. 2000. Review of studies on the thermal resistance of Salmonellae. J. Food Protection. 63: 779-795.

Muljanah, I. dan Suryaningrum, T.D . 2009. Pengaruh bumbu pepes dan pengemasan terhadap mutu Lele Dumbo (Cyprinus carpio) presto selama penyimpanan pada suhu dingin. Prosiding Seminar Nasional Kelautan V Universitas Hangtuah Ke V. Surabaya. 23 April 2009. 10 p. 
Nurrahman dan Isworo, J. T. 2002. Pengaruh Lama Perendaman dan Konsentrasi Tawas terhadap Sifat Fisik, Kimia dan Organoleptik IkanTongkol Asap. Proseding Seminar Teknologi Pangan. PATPI, Malang. $12 \mathrm{p}$.

Nurrahman dan Isworo, J.T. 2005. Peran tawas terhadap peruraian protein ikan tongkol. Jurnal Pangan dan Gizi. Universitas Muhamadiyah Semarang. 64(85): 276-285.

Praseno, O., Krettiawan, H., Asih, S., dan Sudrajat, A. 2010. Uji ketahanan salinitas beberapa strain ikan mas yang dipelihara dalam akuarium. Prosiding Forum Inovasi Teknologi Akuakultur. Pusat Penelitian dan Pengembangan Perikanan Budidaya, Badan Penelitian dan Pengembangan Kelautan dan Perikanan, Jakarta. pp. 93-100

Ratnasari, I. 2002. Kajian Pengunaan Kation Ligan untuk Peningkatan Tekstur Pindang Ikan Mas (Caprynus carpio. Lin). Thesis. IPB, Bogor. $82 \mathrm{p}$.

Riyanto, S., Desmelati, dan Sumarto. 2011. Quality Characteristized Boiled Fish Motan (Thynnichthys polylepis) with Different Boiling Time. Fak Perikanan dan IImu Kelautan Univ Riau. 8 p.

Rusell, A.D. Lethal effects of heat on bacterial physiology and structure. Sci Prog. 86: 115-137.
Subaryono, Ariyani, F., and Dwiyitno. 2004. Penggunaan arang untuk mengurangi kadar histamine ikan pindang tongkol batik (Euthynnus affinis). Journal Pascapanen dan Bioteknologi Kelautan dan Perikanan. 10(3): 27-34.

Tanaka, M. dan Osako, K. 2009. Bantuan teknis untuk industri ikan dan udang skala kecil dan menengah di Indonesia. Kerjasama DKP-JICA. 88 p.

Taylor, R.J. 1980. Food Additives. John Wiley and Sons. Chicchester New York. Brisbane, Toronto.

Wijanarko, S. 2008. Protein struktur. Fein Food energy Info. Diakses tanggal 23 Mei 2013.

Wibowo, S. 2000. Industri Pemindangan Ikan. Jakarta: Penebar Swadaya.

Winarno, F.G. 2004. Kimia Pangan dan Gizi. Penerbit PT Gramedia. 250 p.

Yuliawati, Y. 2004. Pemanfaatan Ikan Mas (Cyprinus carpio) sebagai Produk Pindang Manis. Skripsi Institut Pertanian Bogor. Diakses pada tanggal 4 April 2012.

Unusan, N. 2007. Change in proximate, amino acid and fatty acid contents ini muscle tissue of rainbow trout (Oncorynchus mykiss) after cooking. International Journal Food Science and Tecnology. 42: 1087-1093. 